\title{
Analysis of the Opinions of Social Studies Teachers on Digital Literacy Skills
}

\author{
Cengiz Taşkıran ${ }^{1, *} \&$ Murat Salur ${ }^{2}$ \\ ${ }^{1}$ Faculty of Education, Muş Alparslan University, Muş, Turkey \\ ${ }^{2}$ Faculty of Education, Elazig Firat University, Elazig, Turkey \\ *Correspondence: School of Education, Muş Alparslan University, Muş, Turkey. Tel: 537-912-8523. E-mail: \\ c.taskiran@alparslan.edu.tr
}

Received: February 5, 2020

Accepted: April 9, $2021 \quad$ Online Published: April 16, 2021

doi:10.5430/wje.v11n2p72

URL: https://doi.org/10.5430/wje.v11n2p72

\begin{abstract}
Thanks to digital literacy skills in Social Studies program, it is purposed to provide students with easy access to accurate and reliable information among complex information masses. Digital literacy skill not only provides accurate access to information, but also enables students to study on a legal level, in compliance with ethical rules. In addition, digital literacy makes it easier to use information accessed in daily life, to rearrange information, to generate new information, and to critically evaluate information. In this context, it is expected from a digital literate individual to acquire some knowledge and skills such as using cognitive skills at the highest level, using technological tools in a useful and effective way, accessing information and documents easily, and carrying out this through ethical rules. Social studies course, which plays a key role in providing students with digital literacy skills. In this sense, it contributes to critical and analytical thinking of students by equipping them with cognitive, affective, and social skills. The purpose of this study is to determine the opinions of teachers on digital literacy skills in social studies program. Research group consists of 50 Social Studies teachers working within Ministry of National Education in the provinces of Muş, Malatya, Elazı̆ $\breve{g}$, and Şanlıurfa in 2019-2020 academic year. The opinions of teachers were obtained through semi-structured interview form. The obtained data were analyzed by using qualitative data analysis technique. As a result of this study, it was concluded that social studies teachers have different perceptions of digital literacy skills, and some recommendations were provided in the light of findings.
\end{abstract}

Keywords: social studies lesson, digital literacy, teacher opinions

\section{Introduction}

Given the dizzying pace of scientific and technological developments and the fact that the use of the Internet through computers and phones has become very easy and widespread in the $21^{\text {st }}$ century, access to information and documents has also become faster and easier. However, it can be stated that finding the accurate and useful information among masses of information, bringing them to life by making them functional, and synthesizing all these into a useful form are quite difficult.

It has been inevitable to learn all kinds of technological tools and their effective use in order to find useful and accurate information among complex information masses and to look at the event through a critical perspective. At present, technological tools in general, and more specifically, such tools as computers, mobile phones, and tablets have become an integral part of life. This has enabled faster and easier access to more information. However, it is necessary to learn how to use digital tools and the internet in an appropriate, useful, and effective manner so as to access all this information accurately, effectively, and critically and to get rid of the wrong and manipulative effects of this information. It can be stated that the concept of digital literacy, developed for this purpose, is gaining more and more importance.

According to Özerbaş and Kuralbayeva (2018), digital literacy means using digital technologies effectively and appropriately, conducting relevant research, obtaining new information, and evaluating and interpreting this information through a critical approach.

Digital literacy, which is defined as the ability to access and produce information by using digital technological tools, 
includes such critical thinking skills as research, questioning, problem solving, and decision-making (Duran \& Özen, 2018).

Even though digital literacy includes many skills, cognitive skill basically stands out as the most important skill. The ability to access to some data is not only acquired in digital literacy. In addition to this, it also provides the competence to transfer the obtained data to real life, to use them effectively in real life, and to analyze all these in a critical manner (Martin, 2008). Moreover, digital literacy is important in terms of providing opportunities that enable effective learning to occur and supporting this in every sense in the technology and information age we are in (Belshaw, 2011).

Just as digital literacy ensures the effective use of information and communication technologies, it will also provide many contributions to individuals in personal development through these technologies. Digital literacy, which is a concept that will enable individuals to use these technologies on a safe and legal basis in a way to support participation and production in social life in solving problems encountered at any time in life, is very important in terms of the increase in both the personal development of individuals and the development level of the society (Acar, 2015).

Digital literacy includes having such necessary skills as accessing accurate information by using different technological products, producing, and sharing information, and using technology in the most efficient way in the learning-teaching process (Hamutoğlu et al., 2017: 411).

Upon the rapid increase in digitalization in such sectors as economy, health, service, and education, the concept of digital literacy has started to be used in many fields. Especially, digitalization in the field of education has become widespread with the rapid increase of educational technologies. Therefore, not only students but also teachers and administrators should become digital literate individuals (Sönmez \& Gül, 2014). It is aimed in the education process that students acquire technical skills related to digital technologies within the scope of digital literacy, develop their critical thinking skills, conduct research in accordance with ethical rules, access various information and data from different sources, evaluate, analyze and synthesize these information and data, be able to communicate effectively with people, take constructive social actions, and reflect all of these on their social life (Onursoy, 2018; Özerbaş \& Kuralbayeva, 2018).

In this regard, it can be stated that the digital literacy skill in the Social Studies program is very important and necessary in this period in which the digitalization in education is accelerating. As a matter of fact, it can be observed that acquiring digital literacy skills has become a necessity in this century when the scientific and technological developments accelerate, the communication crosses continents, the access to information has become easier, and the internet usage has become commonplace. Moreover, Kuru (2019) emphasizes that Social Studies course is a course that allows to benefit from technology in terms of content, to benefit from the digital environment, and consequently to gain digital competencies. Therefore, Social Studies course can be considered as one of the important courses aiming to provide students with digital literacy skills since it incorporates digital literacy as a skill and prioritizes digital competencies.

In conjunction with the use of educational technologies at all levels of education, digitalization in education is also increasing day by day. Therefore, in order for the teachers to transfer digital literacy skills to students, they must first acquire this skill themselves. So, it has become an obligation for the teachers to acquire digital literacy skills and develop it at every opportunity. It can be mentioned that the teachers have great responsibilities in transferring digital literacy skills to students.

\section{Purpose of the Study}

The general purpose of this study is to determine the opinions on the digital literacy skills in the Social Studies curriculum in line with the opinions of Social Studies teachers. Within the framework of this general purpose, the following research questions were examined in the study:

$\checkmark$ What do you understand when the digital dimension of literacy is in question?

$\checkmark$ In your opinion, what are the contributions of digital literacy skills to the students?

$\checkmark$ In your opinion, how do the digital and technological tools affect the holistic development of the students? Please explain. 


\section{Method}

Qualitative research method was applied in this study which determines the opinions of the teachers on digital literacy skills in the Social Studies program. The qualitative research is a method that tries to make sense of social problems or some problems related to people in daily life through the unique methods (Creswell, 1998). The use of qualitative research method was considered as appropriate in this study in order to examine the purposes of the research mentioned above and the research questions within the scope of these purposes in depth and to look at the case from the perspective of the participants. Hence, the qualitative research is a very practical method to examine a social phenomenon in depth, to analyze it, to make sense of it, and to interpret the perspectives of the participants. The qualitative research provides in-depth information about social phenomena by examining the natural world of individuals (Kayıkçı \& Uygur, 2012).

According to Yıldırım and Şimşek (2008), the qualitative research is a research in which such methods as observation, interview, and document analysis are frequently used, the opinions are taken in the natural environment, the cases are handled with a holistic approach, and a qualitative process is followed. Merriam (1998) emphasize that the qualitative research method offers the researchers a research table in line with a general and holistic understanding. Therefore, the researchers can make word analysis in line with the relevant research in the natural environment during the qualitative research process and examine the opinions of the participants in detail. Also, qualitative research follows an inductive path. In another saying, there is a process from part to whole. In short, the qualitative research is the process of explaining concepts, topics, cases, facts, meanings, and relationships based on observation, interviews, and documents. In addition to this, it is possible to reach a detailed and deep understanding and comprehension of the subject examined in studies in which the qualitative method is used (Karakaş, 2015: 63).

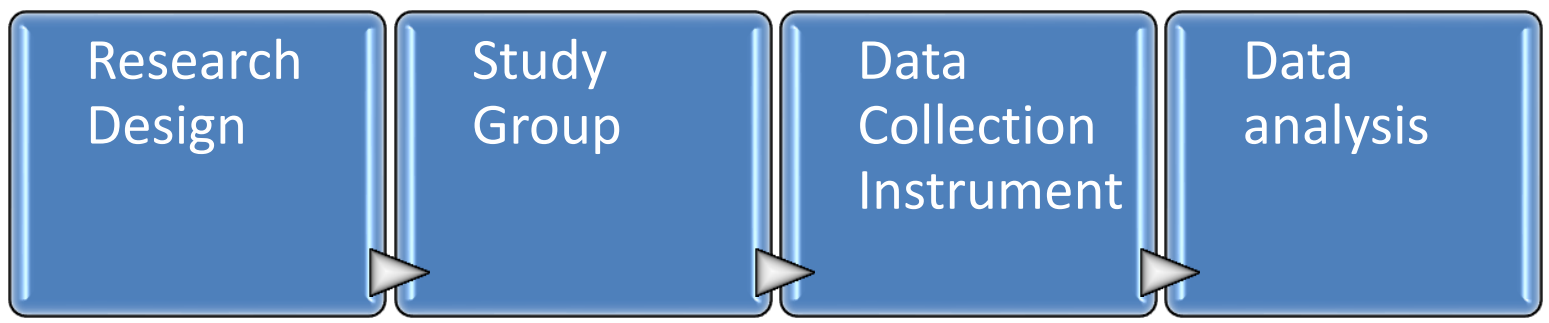

Figure 1. Stages of the Research Method

\subsection{Research Design}

Case study design, which is also suitable for the nature of qualitative research, was used in this study, which is based on determining the views of social studies teachers on digital literacy. Case study is an approach that conducts detailed and in-depth examinations through a systematic understanding by using multiple data collection techniques so as to determine how a system, situation, and case function and what kind of nature it has (Chmiliar, 2010; Zainal, 2007). In other words, the case study is a model based on qualitative understanding that allows one or more cases to be examined in detail and examines the situations in depth through the data collection instruments containing multiple sources (Merriam, 2013; Patton, 2014; Çakmak, Bulut, \& Salur, 2019). The lively and distinct description of the situation examined in the case study, focusing on the specific events in the situation, focusing on the perceptions of both individual and group actors, and presenting the research situation in a rich way allow for a comprehensive evaluation and interpretation of the research (Hitchock and Hughes, 1995: 317).

The case study model is especially used in social sciences, psychology, anthropology, and ecology (Shuttleworth, 2008). In fact, the need for case studies in these fields stems from such reasons as understanding complex social phenomena, making complex situations understandable, and having detailed information about the content of cases (Davey, 1990; Yin, 2014). The use of the case study model in this study is due to such purposes as obtaining detailed opinions of Social Studies teachers on the digital literacy skill in the Social Studies curriculum and determining the perceptions of Social Studies teachers on the concept of digital literacy.

\subsection{Study Group}

The study group in the study consists of 50 Social Studies teachers working in the provinces of Muss, Malatya, Elazı $\breve{g}$, and Sanliurfa in the 2019-2020 academic year. The criterion sampling within the scope of non-random purposeful sampling method was used in determining the study group of the research. The basis for criterion sampling is to study all cases that meet certain pre-determined criteria. These criteria can be created by the researchers or used as a 
previously prepared criteria list. In addition, purposeful sampling method provides serious convenience in terms of discovering and explaining facts, cases, or situations (Yıldırım \& Şimşek, 2008).

The fact that all the teachers in the study group graduated from Social Studies education and had knowledge about the concept of digital literacy was accepted as a criterion in determining the study group. Demographic information about the Social Studies teachers who constitute the study group is presented in Table 1.

Table 1. Demographic Characteristics of Social Studies Teachers

\begin{tabular}{lcccccc}
\hline \multirow{2}{*}{ Gender/Provinces } & \multicolumn{2}{c}{ Male } & \multicolumn{3}{c}{ Female } & \multicolumn{2}{c}{ Total } \\
\cline { 2 - 7 } & $\mathrm{f}$ & $\%$ & $\mathrm{f}$ & $\%$ & $\mathrm{f}$ & $\%$ \\
\hline Muş & 9 & 18 & 5 & 10 & 14 & 28 \\
Malatya & 5 & 10 & 7 & 14 & 12 & 24 \\
Elazı̆ & 10 & 20 & 4 & 8 & 14 & 28 \\
Şanliurfa & 5 & 10 & 5 & 10 & 10 & 20 \\
Total & 29 & 58 & 21 & 42 & 50 & 100 \\
\hline
\end{tabular}

When Table 1 is examined, it is observed that $29(58 \%)$ of the Social Studies teachers constituting the study group are male and that $21(42 \%)$ are female. In addition, 14 (28\%) participants were from Muş, 12 (24\%) from Malatya, $14(28 \%)$ from Elazig, and $10(20 \%)$ from Şanlıurfa.

\subsection{Data Collection Instrument}

After the theoretical dimension of the study was generated, a semi-structured interview form was prepared to obtain the opinions of Social Studies teachers on digital literacy skills in the Social Studies program. While creating the questions in the interview form, attention was paid to such principles as writing easy-to-understand questions, asking open-ended questions, preparing focused questions, avoiding leading, avoiding asking multi-dimensional questions, and organizing the questions logically (Yıldırım \& Şimşek, 2008).

The reason why semi-structured interview form was preferred as a data collection instrument in this study is that it allows comparative results to be obtained in the study. The questions in the semi-structured interview form were created by considering the content of the research and the information in the related literature. In the semi-structured interview form, there are questions related to the content of digital literacy in general and its reflection to the students.

The opinions of two Social Studies field experts from Muş Alparslan and Elazığ Fırat universities were consulted in order to check to what extent the prepared semi-structured interview form serves its purpose, its understandability and expression. In line with the opinions and recommendations of the experts, 1 question in the semi-structured interview form was removed from the form because it was not deemed appropriate for the purpose of the research, and the number of questions was reduced to 3 , and the interview form was finalized.

\subsection{Data Analysis}

The responses to the questions asked to the interviewees were subjected to content analysis in terms of determining the opinions of Social Studies teachers on the digital literacy skill in the Social Studies program. Content analysis is a widely used qualitative research technique. Content analysis provides the researchers a flexible method to analyze textual data. Content analysis offers serious convenience to the researchers to make complex data meaningful and to classify large data under certain categories by making them clearer, easier, and more understandable. Besides, facilitating the systematic classification process, content analysis enables the findings obtained within the scope of the research to be themed, identified, and coded into a meaningful state (Hsieh \& Shannon, 2005).

In this study, by taking the knowledge of the literature into account, the concepts deemed important were coded according to their meanings, and themes were created within the framework of similarities and differences, and the responses were interpreted along with these themes. In order to ensure the reliability of the study, the opinions of two Social Studies field experts from Muş Alparslan and Elazı̆̆ Fırat universities were consulted to confirm whether the opinions given under the three main themes in the study represented these themes on not.

\section{Findings}

In this section, the opinions of Social Studies teachers on digital literacy skills in the Social Studies program are provided and interpreted in line with the determined themes. The frequency and percentage values in the tables show 
the distribution of the participant group opinions in sub-themes.

\subsection{Teacher Perceptions on the Concept of Digital Literacy}

The opinions of the Social Studies teachers, who participated in the interviews, on the digital literacy skill in the Social Studies program are presented below (Table 2).

Table 2. Teacher Opinions on the Concept of Digital Literacy

\begin{tabular}{lll}
\hline \multicolumn{1}{c}{ Concept of Digital Literacy } & $\boldsymbol{f}$ & $\boldsymbol{\%}$ \\
\hline O.1. Digital literacy enables effective use of technological tools. & 12 & 24 \\
O.2. Digital literacy ensures compliance with ethical rules in the execution of informatics processes. & 5 & 10 \\
O.3. Digital literacy enables effective use of social media. & 6 & 12 \\
O.4. Digital literacy enables the acquisition, interpretation, evaluation, and sharing of information. & 8 \\
O.5. Digital literacy enables individuals to communicate quickly and accurately. & 4 \\
O.6. Digital literacy allows analysis of the cases, facts, and issues from different perspectives. & 3 \\
O.7. Digital literacy facilitates access to accurate information. & 6 \\
O.8. Digital literacy makes it easier to generate new information. & 4 \\
O.9. Digital literacy facilitates the holistic analysis of information. & 8 \\
Total & 4 & 8 \\
\hline
\end{tabular}

When the opinions of teachers on the concept of digital literacy are examined, it is observed that $12(24 \%)$ teachers stated that "Digital literacy enables effective use of technological tools"; $5(10 \%)$ teachers, "Digital literacy ensures compliance with ethical rules in the execution of informatics processes"; 6 (12\%) teachers, "Digital literacy enables effective use of social media"; 4 (8\%) teachers, "Digital literacy enables the acquisition, interpretation, evaluation, and sharing of information"; 3 (6\%) teachers, "Digital literacy enables individuals to communicate quickly and accurately"; 6 (12\%) teachers, "Digital literacy allows analysis of the cases, facts, and issues from different perspectives"; 4 (8\%) teachers, "Digital literacy facilitates access to accurate information"; 4 (8\%) teachers, "Digital literacy makes it easier to generate new information", and 6 (12\%) teachers, "Digital literacy facilitates the holistic analysis of information" (Table 2).

Some of the statements of the teachers on the theme of "Teacher opinions on the concept of digital literacy" in Table 2 are given below within the sub-themes determined:

When I think of digital literacy, the first thing that comes to my mind is computers. Of course, digital literacy, which is very different from normal literacy, makes it easier to use computers and similar technological products more effectively. However, I think this situation is not limited to computers only. Using all kinds of technological products can fall into this category. In my opinion, the most important feature in digital literacy is the effective use of technological tools (Social Studies Teacher, 8; 0.1).

Nowadays, it is quite common for the internet to enter every home and even for the small children to surf the internet on the phone. The internet world is a huge virtual world with hundreds and thousands of libraries of information. Therefore, in this period when there is so much information and it is easy to access this information, when it comes to digital literacy, I think of the classification of these information stores within a certain system and in the most reliable way. In other words, this refers to get rid of information confusion and irregularity significantly (Social Studies Teacher, 29; O.7).

Digital literacy has taken its place among the important concepts, especially today because when it comes to digital literacy, I think of keeping up with the digital age we are in. As you know, we are in a digital century. Digital tools are at the center of our lives. We are intertwined with these digital tools every day. Digital tools have become both our entertainment tool and our information tool. Naturally, the information process has been accelerated with digital materials. However, a new problem arose here. How do we get the accurate one among all this information? The answer is to be digitally literate because digital literacy helps us distinguish between correct information and incorrect information (Social Studies Teacher, 40; 0.7).

What is digital literacy? I think we need to understand the concept of digital well before answering this question because our lives are almost completely digitalized. Every part of us is full of digital elements, from the phones we use to the vehicles we ride. For this reason, we are familiar with the concept of 
digital. We are always busy with digital transactions. Every day, we surf on the digital world thanks to our phones and computers. We can access a lot of information within seconds. We can handle many transactions within seconds. However, we wonder how much we obey the ethical rules in doing all these. In fact, I can say that digital literacy gives us the ability to operate on an ethical level, that is, on a moral level. (Social Studies Teacher, 2; O.2).

When it comes to digital literacy, it comes to mind that only phones and computers are used effectively. However, I think this definition is correct, but a limited one because digital literacy refers to know the content of all kinds of digital elements and to have the knowledge and skills of use. Digital literacy means to have full knowledge of digital concepts, to be knowledgeable in this sense, and to advance the ability to use digital elements (Social Studies Teacher, 6; O.1).

When it comes to digital literacy, it is generally understood as getting access to the accurate information. Of course, this is true. However, the digital literate individuals can generate new information as well as quickly access correct information. It is very easy to produce new and original information for the individuals who understand the language of digital. Therefore, in my opinion, digital literacy is the information production process (Social Studies Teacher, 49; 0.8).

Digital literacy refers to be conscious. I am talking about a consciousness and awareness in every field and sense. I think digital literacy means analyzing the events correctly, looking at the issues from a broad perspective, and getting rid of all kinds of narrow patterns (Social Studies Teacher, 10; O.6).

\subsection{Contribution of Digital Literacy Skill to Students}

Another question in the semi-structured interview form is "In your opinion, what are the contributions of digital literacy skills to the students?". The answers given by the study group members to this question are grouped as sub-themes and presented in Table 3.

Table 3. The Contribution of Digital Literacy Skill to the Students According to Teacher Opinion

\begin{tabular}{lll}
\hline \multicolumn{1}{c}{ Contribution of Digital Literacy Skill to the Students } & $\boldsymbol{f}$ & \% \\
\hline O.1. Digital literacy skills increase cognitive skills of the students. & 8 & 16 \\
O.2. Digital literacy skill contributes to critical thinking of the students. & 4 & 8 \\
O.3. Digital literacy skills enable students to engage with technology. & 5 & 10 \\
O.4. Digital literacy makes it easier for students to access reliable information. & 3 & 6 \\
O.5. Digital literacy skill improves effective virtual communication skills of the students. & 5 & 10 \\
O.6. Digital literacy skill enables the students to become conscious internet users. & 6 & 12 \\
O.7. Digital literacy skill enables the students to use both traditional and social media effectively. & 7 \\
O.8. Digital literacy skill provides the students the ability to interpret, analyze, and reproduce information. & 4 & 8 \\
O.9. Digital literacy skill provides the students the operational and technical knowledge and skills. & 6 & 12 \\
O.10. Digital literacy skill enables the students to use digital media for educational purposes. & 2 & 4 \\
Total & $\mathbf{5 0}$ & $\mathbf{1 0 0}$ \\
\hline
\end{tabular}

When the opinions of teachers on the contribution of digital literacy skills to students were examined, 8 (16\%) teachers stated that "Digital literacy skills increase cognitive skills of the students."; 4 (8\%) teachers, "Digital literacy skill contributes to critical thinking of the students."; 5 (10\%) teachers, "Digital literacy skills enable students to engage with technology."; 3 (6\%) teachers, "Digital literacy makes it easier for students to access reliable information."; 5 (10\%) teachers, "Digital literacy skill improves effective virtual communication skills of the students. "; 6 (12\%) teachers, "Digital literacy skill enables the students to become conscious internet users. "; 7 (14\%) teachers, "Digital literacy skill enables the students to use both traditional and social media effectively."; 4 $(8 \%)$ teachers, "Digital literacy skill provides the students the ability to interpret, analyze, and reproduce information."; 6 (12\%) teachers, "Digital literacy skill provides the students the operational and technical knowledge and skills."; and 2 (4\%) teachers, "Digital literacy skill enables the students to use digital media for educational purposes." (Table 3).

Some of the statements of the teachers related to the theme "The status of the contributions of digital literacy skill to students according to teacher opinions" in Table 3 are presented below with their own statements:

Digital literacy will increase the interest of students in technology and technological products. Gaining this skill to students will enable the student to both increase their personal development and become 
citizens who are beneficial to their society in the future. Giving digital literacy skill within the scope of social studies course will enable the students to spend more time with such technological products as computers and phones. However, since this is a conscious spending time, it will benefit students rather than harming them. Moreover, the awareness level of families is also important. Parents also have a great job in supervising children (Social Studies Teacher, 9; O.3).

In our age, knowledge means everything. Especially, accessing information is much easier than before. However, there is a problem that is the difficulty of accessing accurate and reliable information. It is now much easier to reach thousands of information and documents thanks to the internet or social media, but it is a mystery how accurate this information is and how much we can trust this information. In this regard, transferring digital literacy skill to the students will provide great contributions. I think that the students will reach more reliable and accurate information thanks to this skill (Social Studies Teacher, 4 ; 0.4).

Digital literacy equips the students with knowledge and skills to become competent in many fields. We witness that the students often spend time with digital tools and equipment. However, if students do not have digital literacy skill, this situation can harm them. Therefore, I attach great importance to digital literacy. As teachers, if we provide students a setting with good digital literacy education, the students can turn every digital platform into a knowledge home and a school environment. Therefore, digital literacy makes it easier for the students to use technology for educational purposes (Social Studies Teacher, 1 ; 0.10).

Digital literacy will increase both knowledge and skills of the students. But I think it improves the student skills more because digital literacy is basically a skill job. This literacy is the job of using technology and technological tools effectively. If we can make the students digitally literate individuals, we can also ensure that they have a lot of technical knowledge in digital sense and carry out digital operations efficiently. In this respect, digital literacy skills greatly improve the students in terms of technical and operational issues (Social Studies Teacher, 18; 0.9).

Digital literacy skill initially enables the students to access data or information in a healthy way. But I think it is not just about accessing information because digital literacy is a whole. Therefore, it is important for the students to interpret and evaluate this information as well as accessing it. In fact, digital literacy does not only give the students the ability to access information. This literacy enables the students to interpret, evaluate, and even reproduce information (Social Studies Teacher, 33; O.8).

Media means almost everything today. Traditional media used to be quite common and dominant. Now, we can say that the power of traditional media has decreased a little. Instead, social media is hugely popular. However, social media also has a lot of harm. If social media is not used effectively especially for children, there will be too many harmful consequences. Therefore, I think, acquiring digital literacy skills is one of the most basic requirements of this age. Digital literacy is of vital importance for the children to become a conscious media user, especially in the early stages (Social Studies Teacher, 24; 0.7).

Internet usage was not that common in the past. But now, almost every house has internet access. We got all our work done through the internet. This is the same for our students. In fact, they are more intertwined with the internet. Naturally, they are exposed to all kinds of possible risks that may come from here. For this reason, digital literacy skill minimizes the risks that may come from the virtual world and the internet in general. The use of the internet efficiently, quickly, and effectively by the students is possible with digital literacy skill. Therefore, digital literacy skill enables the students to become conscious internet users (Social Studies Teacher, 27; 0.6).

At present, we can see that the quality of communication has changed. In the past, we used to come together, have long chats, and have a nice time. However, the communication of the new generation is now virtual. Everyone is trying to communicate in the virtual world. Even when our students come side by side, our students do not drop their phones and tablets in their hands, and they communicate from there. Therefore, I would like to mention about the communication dimension of digital literacy. Being digital literate has become important in these days when communication is almost completely virtual. Digital literacy enables the students to communicate effectively in virtual environments (Social Studies Teacher, $3 ; \mathbf{O} .5$ ). 


\subsection{The Effects of Digital and Technological Tools on the Holistic Development of Students}

The answers of study group members to the question "In your opinion, how do the digital and technological tools affect the holistic development of the students? Please explain." in the semi-structured interview form are grouped by sub-themes, frequency, and percentages and presented in Table 4.

Table 4. Teacher Opinions on the Positive and Negative Effects of Digital and Technological Tools on the Holistic Development of the Child

\begin{tabular}{|c|c|c|c|}
\hline & The Effects of Digital and Technological Tools on the Holistic Development of the Child & $f$ & $\%$ \\
\hline \multirow{6}{*}{ Positive } & O.1. Digital and technological tools improve the cognitive skills of students. & 6 & 12 \\
\hline & O.2. Digital and technological tools enable the students to focus on various interests. & 4 & 8 \\
\hline & O.3. Digital and technological tools stimulate curiosity and exploration sense of students. & 8 & 16 \\
\hline & O.4. Digital and technological tools enhance the creativity of students. & 2 & 4 \\
\hline & O.5. Digital and technological tools increase the technical skills of students. & 7 & 14 \\
\hline & $\begin{array}{l}\text { O.6. Digital and technological tools improve the knowledge and skills of students related to } \\
\text { software and hardware. }\end{array}$ & 3 & 6 \\
\hline \multirow{6}{*}{ Negative } & O.7. Digital and technological tools cause antisocial impairments for students. & 4 & 8 \\
\hline & O.8. Digital and technological tools cause some physical and mental problems. & 4 & 8 \\
\hline & O.9. Digital and technological tools weaken self-control of students. & 4 & 8 \\
\hline & O.10. Digital and technological tools lead the students to technological addiction. & 5 & 10 \\
\hline & O.11. Digital and technological tools expose students to cyber bullying and abuse. & 3 & 6 \\
\hline & Total & 50 & 100 \\
\hline
\end{tabular}

When the opinions of teachers about the positive and negative effects of digital and technological tools on the holistic development of students are examined, it is observed that whereas there are $30(60 \%)$ teacher opinions on the positive effects of digital and technological tools on the holistic development of students, teachers who gave negative opinions are found to be $20(40 \%)$ in total. In this context, the positive opinions are expressed by the teachers as follows; "Digital and technological tools improve the cognitive skills of students." by $6(12 \%)$ teachers, "Digital and technological tools enable the students to focus on various interests." by 4 (8\%) teachers, "Digital and technological tools stimulate curiosity and exploration sense of students." by $8(16 \%)$ teachers, "Digital and technological tools enhance the creativity of students." by $2(4 \%)$ teachers, "Digital and technological tools increase the technical skills of students." by 7 (14\%) teachers, and "Digital and technological tools improve the knowledge and skills of students related to software and hardware." by $3(6 \%)$ teachers. On the other hand, the negative teacher opinions can be listed as follows; "Digital and technological tools cause antisocial impairments for students." by 4 (8\%) teachers, "Digital and technological tools cause some physical and mental problems." by 4 (8\%) teachers, "Digital and technological tools weaken self-control of students." by $4(8 \%)$ teachers, "Digital and technological tools lead the students to technological addiction." by $5(10 \%)$ teachers, and "Digital and technological tools expose students to cyber bullying and abuse." by $3(6 \%)$ teachers.

Some of the statements of the participants on the theme of "Evaluation of teacher opinions on the positive and negative effects of digital and technological tools on the holistic development of students" are exemplified in Table 4 below:

Digital and technological tools basically develop mental skills. In my opinion, such technological tools will provide many positive cognitive and academic contributions to the students. Using information technologies and digital tools effectively will provide faster access to data, critical filtering of the data, and acquiring reliable information. All of these will allow for the development of mental skills. I can say that it is a very good development for students, especially in the social studies course, to have attainments in teaching these skills" (Social Studies Teacher, 20; O.1).

I think that digital and technological tools will provide very positive contributions to students if they are used effectively. The students who spend a significant part of their time with technological tools can discover some new interests if they use these technologies properly. These new interests can be both in the field of entertainment and in the field of information. Students can further develop themselves through these new areas of interest (Social Studies Teacher, 9; O.2).

Digital and technological tools are like salt water for students. Because the more you drink salt water, the thirstier you are and the more you drink. But their thirst does not pass. In this respect, digital and 
technological tools engage the students with itself. If it is not used beneficially, it may have some harm. But if these tools are used consciously, the curiosity sense of students increases. For example, the students who discover new knowledge through technological tools will want to discover some other new and different information, and thus their constant sense of wonder remains alive. The students will always be in an effort to discover new information and new situations; therefore, the feelings of curiosity and discovery will always develop (Social Studies Teacher, 45; O.3).

Students who are constantly intertwined with digital and technological tools will always want to research, see, and know new and different things. In case of a problem, the students immediately try to solve that problem thanks to the information they have acquired before. Digital and technological tools both provide students with knowledge and skills. The students also try to produce different and original products through the new knowledge and skills they have acquired. In fact, we can say that all these improve creative thinking skills of students because digital and technological tools constantly push students to new situations. The students also develop their creativity by keeping up with this situation (Social Studies Teacher, 36; 0.4).

Digital and technological tools provide new skills to the students. For example, when our smart board fails in the classroom or when we have a different technological tool problem, our students can solve that problem immediately before us. I think technological tools are beneficial for students in this respect because the technical skills and abilities of the students related to the technological equipment are increasing day by day. Actually, we can say that this situation is a necessity in this age (Social Studies Teacher, 38; 0.5).

Digital and technological tools provide both software knowledge and hardware knowledge to the students. Our students are very interested in such tools. For example, our students know very well the parts of phones or computers, that is, their hardware. In fact, some of our students not only know the parts of such technological tools, but also are also contextually interested in the software aspect. They are constantly in curiosity, research, and investigation. Of course, this situation improves the software and hardware knowledge of the students about technology. But it is not just about information. The technical skills of the students in this sense are also excellent. Therefore, I think this is the most positive achievement of digital and technological tools (Social Studies Teacher, 50; O.6).

I think the digital and technological tools have negative aspects as well as their positive aspects because the time the child spends on the computer or phone is constantly increasing. Even small children spend hours in front of such technological tools. They spend the time and energy they need to spend with their friends or family with technological products. In this respect, we can call it a situation like addiction. Of course, because of this, there may be a life disconnected from social life, as well as psychological, mental, and even physical disorders (Social Studies Teacher, 16; O.8).

Of course, the digital and technological tools make life much easier and provide many benefits. However, it has also downsides. We constantly witness that both our children and our students spend their time on phones, computers, or tablets. They hardly have a social life. All their societies have become virtual channels. That is why our students do not know exactly how to behave when they are involved in society. They are afraid of society. They are afraid of getting involved in society. I think the main reason for all this is that our students spend all their time with digital and technological tools (Social Studies Teacher, $11 ; 0.7$ ).

Digital and technological tools engage students like an addiction. Students always have their phones in their hands and never leave them at home, at school, or even in any environment. In fact, when those devices run out of charge, the students react as if they run out of oxygen. For this reason, I think the biggest negative side of those technological tools is that they are addictive (Social Studies Teacher, 2; 0.10).

Children who have not received digital literacy training or who do not learn how to use digital tools consciously from their families face enormous risks. The worst of these risks is that our children are sexually abused in the virtual world. This situation darkens the lives of our children. It literally takes their future away from them. Other than that, bullying situations are not just outside as the way they used to be. There is cyber bullying now. Of course, the benefits of digital and technological tools cannot be denied. However, there are many such negative and even risky situations. We cannot ignore them. In this respect, the teachers and families have important responsibilities in order to ensure that 
the students benefit from technology consciously (Social Studies Teacher, 33; O.11).

\section{Conclusion, Discussion, and Recommendations}

It is possible to say that social life has started to evolve into digital life and that digitalization has increased its importance in this sense as technology and technological products affect many areas from the economy sector to the health sector, from the service sector to the education sector. Digital literacy has started to gain more importance especially as the education and educational institutions enter into a process towards digitalization at all levels and rapidly. Therefore, it is clear that the courses provided in schools will stay away from all these developments. It can be understood that steady, systematic, and consistent education systems are needed in order to catch up with the era and its requirements and even go beyond. Considering these reasons, it is a fact that the content of the lessons given at schools should be shaped accordingly.

It was purposed in this study to take the opinions of social studies teachers about digital literacy skills, to analyze them by dividing them into certain categories, and finally to make some recommendations. In addition, it can be mentioned that this study is of great importance in terms of providing some contributions to the studies conducted or to be conducted in this field.

In this study, in line with the opinions of Social Studies teachers, it is possible to summarize the results obtained in the interviews about the evaluation of digital literacy skills in the social studies program as follows:

The opinions of Social Studies teachers on the concept of digital literacy are as follows: Social Studies teachers emphasized that the digital literacy:

- enabled the effective use of technological tools,

- facilitated compliance with ethical rules in the execution of IT transactions,

- facilitated access to accurate information,

- provided effective use of social media,

- made it easier to get information, interpret, evaluate, and share information,

- provided a fast and accurate communication,

- made it easier to analyze the cases, facts, and issues from different perspectives,

- facilitated to generate new knowledge,

- $\quad$ provided convenience in holistic analysis of information (Table 2).

There are three basic principles in internationally accepted definitions of digital literacy. These principles are as follows (Media Awareness Network, 2010):

- Digital literacy is the knowledge and ability to access and use software applications and hardware devices in various digital media such as computers, mobile phones and internet technology.

- Digital literacy is the state of critical understanding of digital media content and practices.

- Digital literacy is to generate information and capacity to be created with digital technology.

The opinions mentioned by the social studies teachers on this issue are in parallel with the three principles of internationally accepted digital literacy.

When the opinions of social studies teachers on the contribution of digital literacy skill to the students are examined, the contributions of this skill to the students can be summarized as follows:

- Digital literacy skill contributes to the critical thinking of students,

- It allows the students to be integrated with technology,

- It facilitates the access of students to reliable information,

- It improves the effective virtual communication skills of students,

- It enables students to be conscious internet users,

- It enables students to use both traditional and social media effectively,

- It provides students with the ability to interpret, analyze, and reproduce information,

- It provides students with operational and technical knowledge and skills, 
- $\quad$ It enables students to use digital media for educational purposes (Table 3).

In a study conducted by Onursoy (2018: 1007), the characteristics of digital literate individuals are briefly expressed as follows:

- Digital literate individuals can actively access and maintain digital information they need in solving any problem,

- Digital literate individuals can decipher the information obtained by them for their own use, evaluate them, and add new information to them.

In another study conducted by Hamutoğlu et al. (2017: 411), the characteristics of digital literate individuals are briefly defined as follows:

- Digital literate individuals use different technologies effectively, quickly, and accurately,

- Digital literate individuals can easily access accurate information from reliable sources,

- Digital literate individuals acquire the ability to interpret, analyze, reproduce and share information,

- Digital literate individuals use technology meaningfully and efficiently in their learning-teaching processes.

In their study, Sönmez and Gül (2014) explained the characteristics of digital literate individuals are as follows:

- Digital literate individuals find solutions to problems in the digital setting,

- Digital literate individuals have the knowledge and skills of digital equipment,

- Digital literate individuals use digital media for educational purposes and personal development.

It is observed in the studies carried out by Onursoy (2018: 1007), Hamutoğlu et al., (2017: 411), and Sönmez and Gül (2014) that there are similarities between the definitions of digital literate individuals and the results obtained in this study.

Finally, another result which is obtained in this study is the issue of the positive or negative effects of digital and technological tools on the holistic development of students. When the opinions of teachers on the positive or negative effects of digital and technological tools on the holistic development of students are examined, the following important results appear: Whereas $60 \%$ of the study group members participating in the study expressed positive opinions on this issue, $40 \%$ of them stated that digital and technological tools had negative effects on children. The teachers who expressed positive opinions on this matter mounted the following arguments:

- Digital and technological tools improve the cognitive skills of students,

- It allows the students to focus on various interests,

- It triggers the curiosity and discovery sense of students,

- It improves the creativity of students,

- It increases the technical skills of students,

- It develops the knowledge and skills of students about software and hardware (Table 4).

The teachers who expressed negative opinions on digital and technological tools for the holistic development of students generated the following arguments:

- Digital and technological tools cause antisocial disorders for the students,

- It causes students to experience some physical and mental problems,

- It weakens self-control of the students,

- It leads the students to technological addiction,

- It causes students to be exposed to cyber bullying and abuse (Table 4).

In the study titled "A Comparative Analysis of TV And YouTube Viewing Habits of Children Within the Context of Digital Literacy”, Kalan (2018) concluded that the children stay at home all the time and spend time with digital and technological tools whenever they want, especially in the city life, that they are vulnerable to all the adverse effects and risks of such tools, and that the risk is exacerbated by the lack of awareness of families. It was understood that whereas these results obtained by Kalan (2018) and the results obtained in this study (Table 4) are in parallel in terms of some aspects (negative opinions of teachers about digital and technological tools), they are in conflict in terms of 
some other aspects (positive teacher opinions about digital and technological tools).

The following recommendations can be generated in line with this research:

- Initially, the teachers should have knowledge and skill in this field in order to ensure the correct and efficient transfer of digital literacy skill to the students. Therefore, seminars or conferences on this issue can be held for the teachers.

- In addition to the Social Studies course, some acquisitions can be added to other courses so as to transfer digital literacy skill.

- Joint activities on the transfer of digital literacy skill can be organized within the framework of the cooperation of teachers, school administrators, and parents.

- The required emphasis can be given to practical dimension of the courses rather than the theoretical explanations in order to establish this skill fully.

- Digital literacy can be provided to students thanks to the applications on how to access accurate, reliable, and practical information through the shortest and easiest method and how to use such technological products as computers, tablets, and phones more efficiently.

As a result, it was concluded in this study that Social Studies teachers generated similar contents and definitions to the contents and definitions included in some studies about digital literacy (Hamutoğlu et al., 2017; Onursoy, 2018; Sönmez \& Gül, 2014). In addition, in the light of all the obtained data, it was purposed to contribute to the relevant field by presenting the recommendations above.

\section{References}

Acar, Ç. (2015). Anne ve Babaların İlkokul Ortaokul ve Lise Öğrencisi Çocukları İle Kendilerinin Dijital Okuryazarlıklarına İlişkin Görüşleri. Yayımlanmamış Yüksek Lisans Tezi, Ankara Üniversitesi Eğitim Bilimleri Enstitüsü, Ankara.

Belshaw, D. A. J. (2011). What is Digital Literacy? A Pragmatic İnvestigation. Retrieved from http://neverendingthesis.com/index.php/Main_Page

Çakmak, Z., Bulut, B., \& Salur, M. (2019). Öğretmen Adayları Perspektifinden Sosyal Bilgiler Dersinin Hedef ve Rolleri. B. Yenihan, G. Cerev ve Ö. Yusufoğlu (Ed.), 2. Uluslararası Sosyal Bilimler ve Inovasyon Kongresi bildiriler kitabı içinde (ss. 868-873). Elazığ: Fırat Üniversitesi.

Chmiliar, L. (2010). Multiple-case Designs. In A. J. Mills, G. Eurepas \& E. Wiebe (Eds.), Encyclopedia of case study research (pp 582-583). USA: SAGE Publications.

Creswell, J. W. (1998). Qualitative Inquiry and research design: Choosing among five traditions. Thousand Oaks, CA: Sage Publications.

Davey, L. (1990). The application of case study evaluations. Practical assessment, research, and evaluation, 2 (1), 9. https://doi.org/10.7275/02g8-bb93

Duran, E., \& Özen, N. E. (2018). Türkçe Derslerinde Dijital Okuryazarlık. Türkiye Eğitim Dergisi, 3(2), $31-46$. https://doi.org/11..11111/ted.xx

Hamutoğlu, N. B., Canan Güngören, Ö., Kaya Uyanık, G., \& Gür Erdoğan, D. (2017). Dijital Okuryazarlık Ölçeği: Türkçe 'ye Uyarlama Çalışması. Ege Eğitim Dergisi, 1(18), 408-429. https://doi.org/10.12984/egeefd.295306

Hitchcock, D. H., Hitchcock, G., \& Hughes, D. (1995). Research and the teacher: A qualitative introduction to school-based research. Psychology Press.

Hsieh, H.-F., \& Shannon, S. E. (2005). Three Approaches to Qualitative Content Analysis. Qualitative Health Research, 15(9), 1277-1288. https://doi.org/10.1177/1049732305276687

Kalan, Ö. (2018). Dijital Okuryazarlık Boyutunda Çocukların Televizyon ve Youtube İzleme Alışkanlıklarının Karşılaştırmalı Bir İncelemesi. Uluslararası Dijital Çă̆da İletişim Sempozyumu Kitabı içinde. Mersin.

Karakaş, Z. (2015). Sosyal Bilimlerde Nitel Araştırma Yöntemleri. Manevi Temelli Sosyal Hizmet Araştırmaları Dergisi, 1(1), 62-80.

Kayıkçı, K., \& Uygur, Ö. (2012). İlköğretim Okullarının Denetiminde Mesleki Etik (Bir Durum Çalışması). Kuram ve Uygulamada Ĕ̈itim Yönetimi Dergisi, 18(1), 65-94. 
Kuru, E. (2019). Sosyal Bilgiler Öğretmen Adaylarının Dijital Okuryazarlık Kavramına İlişkin Görüşleri. Electronic Turkish Studies, 14(3), 1629-1648. https://doi.org/10.29228/TurkishStudies.22563

Martin, A. (2008). Digital Literacy and the 'Digital Society. C. Lankshear, M. Knobel (Ed.), Digital Literacies: Concepts, Policies and Practices içinde (s.151-174). New York: PeterLang.

Media Awareness Network (2010). Digital literacy in Canada: From Inclusionto Transformation. A Submission to the Digital Economy Strategy Consultation. Retrieved from http://www.ic.gc.ca/eic/site/028.nsf/eng/00454.html

Merriam, S. (1998). Qualitative research and case study applications in education. San Francisco: Jossey-Bass.

Merriam, S. B. (2013). Nitel Araştırma: Desen ve Uygulama İçin Bir Rehber (3. Baskıdan Çeviri, Çeviri Editörü: S. Turan). Ankara: Nobel Yayın Dağıtım.

Onursoy, S. (2018). Üniversite Gençliğinin Dijital Okuryazarlık Düzeyleri: Anadolu Üniversitesi Öğrencileri Üzerine Bir Araştırma. Gümüşhane Üniversitesi Illetişim Fakültesi Elektronik Dergisi. 6(2), 989-1013. https://doi.org/10.19145/e-gifder.422671

Özerbaş, M. A., \& Kuralbayeva, A. (2018). Türkiye ve Kazakistan Öğretmen Adaylarının Dijital Okuryazarlık Düzeylerinin Değerlendirilmesi. Muğla Sttkı Koçman Üniversitesi Eğitim Fakültesi Dergisi, 5(1), 16-25. https://doi.org/10.21666/muefd.314761

Patton, M. Q. (2014). Nitel Araştırma ve Değerlendirme Yöntemleri (Qualitative Research \& Evaluation MethodsÇeviri Editörü: M. Bütün, S.B. Demir). Ankara: Pegem Akademi.

Shuttleworth, M. (2008). Case study research design. Retrieved from http://www.experiment-resources.com/case-studyresearch-design.html

Sönmez, E. E., \& Gül, H. Ü. (2014). Dijital Okuryazarllk ve Okul Yöneticileri. In M. Akgül vd. (Ed.), 19. Türkiye’de İnternet Konferansı bildiriler kitabı içinde (ss. 171-179). İzmir: Yaşar Üniversitesi.

Yıldırım, A., \& Şimşek, H. (2008). Sosyal Bilimlerde Nitel Araştırma Yöntemleri. Ankara: Seçkin Yayıncılık.

Yin, R. K. (2014). Case study methods: design and methods (5. Bask1). Thousand Oaks: Sage Pbc.

Zainal, Z. (2007). Case study as a research method. Jurnal kemanusiaan, 5(1). 1-6.

\section{Copyrights}

Copyright for this article is retained by the author(s), with first publication rights granted to the journal.

This is an open-access article distributed under the terms and conditions of the Creative Commons Attribution license (http://creativecommons.org/licenses/by/4.0/). 